\title{
The Application of The Problem Based Learning Model to Improve Student Learning Outcomes in Natural Science Lesson in Class IV of SD Negeri Ngrajek 1
}

\section{Lenny Aprilitsnaeni}

SDN Ngrajek 1

lennyaprilitsnaeni@gmail.com

\section{Article History}

received 3/12/2020

\begin{abstract}
The science learning process carried out by the teacher is still conventional which tends to make students feel bored and does not provide opportunities for students to be active in learning so that there are still many students who have difficulty following the learning process which results in low student learning outcomes. This problem is also experienced by students at $S D$ Negeri Ngrajek 1. The purpose of this study is to improve student learning outcomes through the Problem Based Learning learning model for fourth grade students at SD Negeri Ngrajek 1. The research form is Classroom Action Research (CAR). Based on the percentage of student learning outcomes, the average value in each cycle can be obtained, namely in the first cycle there was an increase in the average value of 8.75, namely the initial average value of 66.25 increased to 75. Classical student learning outcomes are still classified as moderate. with an average acquisition of 79 in the 70-79 interval in the medium category. In the second cycle the average score of students increased by 12.5, which was originally an average of 66.5 students in the second cycle the average value was 79 in the medium category. In cycle III the average score of students also increased by 14.5, which was originally 66.5 students on average in cycle III the average value was 81 . Classical student learning outcomes were in the interval 80-89 in the high category. This means that learning through the Problem Based Learning method can improve the learning outcomes of fourth grade students at SD Negeri Ngrajek 1.
\end{abstract}

Keywords: science learning, learning outcomes, problem based learning

\begin{abstract}
Abstrak
Proses pembelajaran IPA yang dilakukan guru masih bersifat konvensional yang cenderung membuat siswa merasakan kebosanan dan tidak memberikan kesempatan bagi siswa untuk aktif dalam pembelajaran sehingga masih banyak siswa yang kesulitan dalam mengikuti proses pembelajaran yang mengakibatkan hasil belajar siswa tergolong rendah. Permasalahan tersebut juga dialami siswa di SD Negeri Ngrajek 1. Tujuan dari penelitian ini adalah untuk meningkatkan hasil belajar siswa melalui model pembelajaran Problem Based Learning pada siswa kelas IV SD Negeri Ngrajek 1. bentuk penelitiannya adalah Penelitian Tindakan Kelas (PTK). Berdasarkan persentase hasil belajar siswa dapat diperoleh nilai rata-rata pada setiap siklus yaitu pada siklus I terjadi peningkatan nilai rata-rata sebesar 8,75 yaitu nilai rata-rata awal sebesar 66,25 meningkat menjadi 75. Hasil belajar siswa secara klasikal masih tergolong sedang dengan perolehan rata-rata sebesar 79 berada pada interval 70-79 pada kategori sedang. Pada siklus II nilai rata-rata siswa mengalami peningkatan sebesar 12,5, yang semula rata-rata siswa 66,5 pada siklus II nilai rata-rata sebesar 79 dengan kategori sedang. Pada siklus III nilai rata-rata siswa juga mengalami peningkatan sebesar 14,5, yang semula rata-rata siswa 66,5 pada siklus III nilai rata-rata sebesar 81. Hasil belajar siswa secara klasikal berada pada interval 80-89 pada kategori tinggi. Hal ini berarti pembelajaran melalui metode Problem Based Learning dapat meningkatkan hasil belajar siswa kelas IV SD Negeri Ngrajek 1.
\end{abstract}

Kata kunci: Pembelajaran IPA, Hasil Belajar, Problem Based Learning

Social, Humanities, and Education Studies (SHEs): Conference Series

p-ISSN 2620-9284 https://jurnal.uns.ac.id/shes e-ISSN 2620-9292 


\section{PENDAHULUAN}

Pendidikan merupakan salah satu faktor utama yang diyakini mampu meningkatkan sumber daya manusia sehingga dapat menciptakan manusia produktif yang mampu memajukan bangsanya. Keberhasilan dari pencapain pendidikan tergantung pada pembelajaran yang berlangsung. Pembelajaran di Indonesia banyak menawarkan berbagai macam model pembelajaran yang dapat digunakan oleh para guru. Guru harus kreatif dalam mengembangkan model pembelajaran tersendiri yang sesuai dengan kondisi nyata ditempat kerja masing-masing.

Pembelajaran IPA pada sekolah terutama pada sekolah dasar (SD) diharapkan dapat menjadi wahana bagi siswa untuk mempelajari diri sendiri dan alam sekitarnya, serta prospek pengembangan lebih lanjut dalam menerapkannya di dalam kehidupan sehari-hari. IPA bukan hanya penguasaan kumpulan pengetahuan yang berupa fakta-fakta, konsep-konsep, atau prinsip-prinsip saja, melainkan juga merupakan suatu proses penemuan.

Guru berperan penting dalam proses kegiatan pembelajaran karena berhasil tidaknya siswa dalam belajar tergantung pada kemampuan guru dalam mengkoordinasikan komponen-komponen pembelajaran pada setiap mata pelajaran khususnya dalam pembelajaran IPA. Dalam pencapaian komponen yang ditetapkan, banyak hal yang harus dilakukan guru seperti menentukan metode, media, model, dan keterampilan mengajar yang mampu memotivasi siswa agar lebih bersemangat dalam setiap aktivitas pembelajaran.

Model pembelajaran yang digunakan guru sangat mempengaruhi tercapainya sasaran belajar, oleh sebab itu guru perlu memilih model yang tepat dari sekian banyak model pembelajaran, jangan menggunakan model pembelajaran berdasarkan kebiasaan akan tetapi berdasarkan materi dan sasaran yang akan dicapai. Setiap siswa memilki keunikan masing-masing dalam berbagai hal, hal ini menujukkan bahwa pemahaman guru terhadap model pembelajaran yang akan digunakan tidak dapat diabaikan.

Pada dasarnya tidak ada model yang paling ideal. Masing-masing mempunyai kelebihan dan kekurangan sendiri. Hal ini sangat bergantung pada tujuan yang hendak dicapai guru, ketersediaan fasilitas dan kondisi siswa. Proses belajar akan lebih efektif jika guru dapat mengkondisikan semua siswa terlibat aktif dan terjadi hubungan yang dinamis dan saling mendukung antar siswa satu dengan siswa yang lain sehingga mencapai hasil belajar yang maksimal. Namun kenyataan di lapangan tidak seperti itu, proses pembelajaran yang dilakukan guru masih bersifat konvensional yang cenderung membuat siswa merasakan kebosanan dan tidak memberikan kesempatan bagi siswa untuk aktif dalam pembelajaran. Sehingga masih banyak siswa yang kesulitan dalam mengikuti proses pembelajaran yang mengakibatkan hasil belajar siswa tergolong rendah.

Model pembelajaran adalah sebagai suatu cara belajar yang memperlihatkan pola pembelajaran tertentu (Zusnani, 2016: 12). Dalam pola tersebut dapat dilihat kegiatan siswa di dalam mewujudkan kondisi belajar atau sistem lingkungan yang menciptakan terjadinya sistem belajar bagi siswa

Suprijono (2015: 45) menyatakan bahwa model pembelajaran adalah sebagai kerangka konseptual yang melukiskan prosedur sistematis dalam mengorganisasikan pengalaman belajar untuk mencapai tujuan belajar. Sedangkan menurut Sagala (2019: 61) model pembelajaran adalah komunikasi dua arah untuk membelajarkan siswa menggunakan asas pendidikan maupun teori belajar..

Metode yang digunakan dalam penelitian ini adalah Problem Based learning (PBL). Wulandari (2016: 180) menyatakan bahwa Problem Based Learning (PBL) merupakan pembelajaran yang memiliki esensi berupa menyuguhkan berbagai situasi bermasalah yang autentik dan bermakna kepada siswa. Sebagai tambahan, dalam Problem Based Learning (PBL) peran guru adalah menyodorkan berbagai 
masalah autentik sehingga jelas bahwa dituntut keaktifan siswa untuk dapat menyelesaikan masalah tersebut. Melalui model Problem Based Learning (PBL) dapat mengaktifkan siswa terlibat langsung dalam proses pembelajaran. Siswa tidak hanya menjadi objek pembelajaran tetapi sebagai subjek yang dapat terlibat dalam proses pembelajaran berlangsung.

Menurut Sudjana (2018: 56) menyatakan " Hasil belajar adalah kemampuankemampuan yang dimiliki siswa setelah ia menerima pengalaman belajarnya". Sedangkan menurut Rusman (2018: 67) menyatakan bahwa "kemampuan yang dimiliki siswa setelah ia menerima pengalaman belajar, Dapat diartikan juga hasil belajar adalah sejumlah pengalam yang diperoleh siswa yang mencangkup beberapa ranah diantaranya ranah kognitif, afektif, dan psikomotor". Hasil belajar adalah tingkat pemahaman siswa dalam melakukan kegiatan pembelajaran yang dimana hasil belajar terdapat penilaian pengetahuan, sikap, dan keterampilan Maka dibawah ini adalah tiga pengertian dari ranah pengetahuan, ranah sikap dan ranah keterampilan: (a) Ranah kognitif yaitu berkenaan dengan hasil belajar yang terdiri dari pengetahuan, pemahaman yang disebut sebagai ranah kognitif; (b) Ranah afektif berkenaan dengan sikap yang terdiri dari, penerimaan, jawaban atau reaksi, penilaian; (c) Ranah psikomotor yaitu berkenaan dengan hasil belajar dalam keterampilan dan kemampuan bertindak.

Sedangkan menurut Gagne dalam Suprijono (2015: 6) menyatakan bahwa hasil belajar berupa : (a) Informasi verbal yaitu kapabilitas mengungkapkan pengetahuan dalam bentuk bahasa, baik lisan maupun tertulis; (b) Keterampilan intelektual yaitu kemampuan mempresentasikan konsep dan lambang; (c) Strategi kognitif yaitu kecakapan menyalurkan dan mengarahkan aktivitas kognitifnya sendiri; (d) Keterampilan motorik yaitu kemampuan melakukan serangkaian gerak jasmani dalam urusan dan koordinasi, sehingga terwujud otomatisme gerak jasmani; (e) Sikap adalah kemampuan menerima atau menolak objek berdasarkan penilaian terhadap objek tersebut.

Shoimin (2017: 130) mengemukakan bahwa pengertian dari model Problem Based Learning adalah model pengajaran yang bercirikan adanya permasalahan nyata sebagai konteks untuk para siswa belajar berfikir kritis dan keterampilan memecahkan masalah serta memperoleh pengetahuan. Menurut Rusman (2018: 229) mengatakan bahwa Problem Based Learning merupakan inovasi dalam pembelajaran karena pembelajaran berbasis masalah kemampuan berpikir siswa betul-betul dioptimalkan melalui proses kerja kelompok atau tim yang sistematis, sehingga siswa dapat memberdayakan serta mengasah, menguji, dan mengembangkan kemampuan berpikirnya secara kesinambungan.

Abidin, (2016: 159) menyatakan pengertian model Problem Based Learning merupakan model pembelajaran yang di kembangkan untuk membantu guru untuk mengembangkan kemampuan berpikir dan keterampilan memecahkan masalah pada siswa untuk berperan aktif dalam aktivitas memikirkan masalah yang berhubungan dengan hidupan sehari-hari menemui prosedur yang di perlukan untuk menemukan informasi yang dibutuhkan, memikirkan situasi yang di butuhkan, memikirkan situasi kontekstual, memecahkan masalah dan memberi solusi dari masalah tersebut.

Menurut Rusman (2018: 232) berpendapat karakteristik model Problem Based Learning (PBL) antara lain sebagai berikut: (1) Permasalahan menjadi starting point dalam belajar atau saat pelajaran berlangsung; (2) Permasalah yang diangkat adalah permasalahan yang ada di dunia nyata atau kehidupan seharihari yang tidak terstruktur; (3) Permasalahan membutuhkan perspektif ganda (multiple perspetion); (4) Permasalahan, menantang pengetahuan yang dimiliki oleh siswa, sikap, dan kompetensi yang kemudian membutuhkan identitas kebutuhan belajar dan bidang baru dalam belajar atau saat pembelajaran berlangsung; (5) 
Belajar pengarahan diri menjadi hal yang utama atau di dahulukan; (6) Pemanfaatan sumber pengetahuan yang beragam, penggunaannya dan evaluasi sumber informasi merupakan proses yang esensial dalam Problem Based Learning (PBL); (7) Belajar adalah kolaboratif, komunikasi, dan kooperatif.

Sedangkan menurut Nur (2015:15) menyatakan karakteristik model

Problem Based Learning (PBL) sebagai berikut :

1) Pembelajaran pertanyaan atau masalah

Problem Based Learning (PBL) bukan hanya mengorganisasikan prinsip-prinsip atau keterampilan akademik tertentu, tetapi mengorganisasikan pengajaran di sekitar pertanyaan dan masalah yang kedua-duanya secara social penting dan secara pribadi bermakna untuk siswa. Mereka mengajukan situasi kehidupan nyata yang autentik, menghindari jawaban sederhana dan memungkinkan adanya berbagai macam solusi untuk situasi ini.

2) Berfokus pada keterkaitan antar disiplin

Meskipun pembelajaran berbasis masalah mungkin berpusar pada mata pelajaran tertentu, tetapi dalam pemecahannya melalui solusi, siswa dapat meninjaunya dari berbagai mata pelajaran yang ada.

3) Penyelidikan Autentik

Menurut Rusman (2018: 237) model pembelajaran ini diberikan dengan tujuan sebagai berikut : (a) Mengembangkan keterampilan berpikir tingkat tinggi; (b) Belajar berbagai peran orang dewasa; (c) Menjadi pelajar yang otonom dan mandiri

Penggunaan model Problem Based Learning (PBL) mempunyai langkahlangkah dalam melaksanakan proses pembelajaran. Menurut Mulyasa (2014: 145), sintaks untuk model PBL dapat disajikan seperti pada:

Tabel 1. Sintaks Model Problem Based Learning (PBL)

\begin{tabular}{ll}
\hline \multicolumn{1}{c}{ Fase } & \multicolumn{1}{c}{ Perilaku Guru } \\
\hline $\begin{array}{l}\text { Fase 1. } \\
\text { tentang permasalahannya } \\
\text { kepada siswa. }\end{array}$ & $\begin{array}{l}\text { Guru membahas tujuan pembelajaran, } \\
\text { mendeskripsikan, dan memotivasi untuk terlibat } \\
\text { dalam kegiatan mengatasi masalah. }\end{array}$ \\
\hline $\begin{array}{l}\text { Fase 2 } \\
\text { Mengorganisasikan siswa } \\
\text { untuk belajar }\end{array}$ & $\begin{array}{l}\text { Guru membantu siswa untuk mendefinisikan dan } \\
\text { mengorganisasikan tugas-tugas belajar yang terkait } \\
\text { dengan permasalahannya. }\end{array}$ \\
\hline $\begin{array}{l}\text { Fase 3 } \\
\text { Membantu investigasi } \\
\text { mandiri/kelompok }\end{array}$ & $\begin{array}{l}\text { Guru mendorong siswa untuk } \\
\text { mendapatkan informasi yang tepat, }\end{array}$ \\
\hline $\begin{array}{l}\text { Fase 4 } \\
\text { Mengembangkan dan } \\
\text { mempresentasikan hasil }\end{array}$ & $\begin{array}{l}\text { Guru menan eksperimen, } \\
\text { menyiapkan hasil-hasil yang tepat seperti laporan, } \\
\text { rekaman video, dan model-model untuk membantu } \\
\text { mereka menyajikan kepada orang/kelompok lain. }\end{array}$ \\
\hline $\begin{array}{l}\text { Fase 5 } \\
\text { Menganalisis dan }\end{array}$ & $\begin{array}{l}\text { Guru membantu siswa untuk melakukan refleksi } \\
\text { terhadap investigasinya dan proses-proses yang }\end{array}$ \\
mengevaluasi proses & mereka gunakan. \\
\hline
\end{tabular}

Menurut Amir (2019: 32) kelebihan Problem Based Learning (PBL) ada di perancangan masalah. Masalah yang diberikan haruslah dapat merangsang dan memicu siswa untuk menjalankan pembelajaran dengan baik. 
Kelebihan Model Problem Based Learning (PBL) menurut Syarif (2018:46) strategi pembelajaran memiliki beberapa kelebihan yaitu diantaranya : (a) Melatih siswa untuk mendesain suatu penemuan; (b) Berpikir dan bertindak kreatif; (c) Siswa dapat memacahkan masalah yang dihadapi secara realistis atau dalam kehidupan sehari-hari; (d) Mengidentifikasi dan mengevaluasi penyelidikan masalah yang terjadi; (e) Menafsirkan dan mengevaluasi hasil pengamatan yang sebelumnya sudah diamati; (f) Merangsang bagi perkembangan kemajuan berpikir siswa untuk menyelesaikan suatu permasalahan yang dihadapi dengan tepat atau benar; ( $g$ ) Dapat membuat pendidikan lebih relevan dengan kehidupan sehari-hari atau dunia nyata.

Kekurangan Model Problem Based Learning menurut Syarif (2018: 47) model Problem Based Learning ini memiliki beberapa kekurangan yaitu diantaranya: (1) Beberapa pokok bahasan sangat sulit untuk menerapkan model ini. Misalnya terbatasnya sarana dan prasana atau media pembelajaran yang dimiliki dapat menyulitkam siswa untuk melihat dan mengamati serta akhirnya dapat menyimpulkan konsep yang diajarkan oleh pendidik; (2) Membutuhkan alokasi waktu yang lebih panjang; (3) Pembelajaran hanya berdasarkan masalah.

\section{METODE}

Jenis penelitian yang dipilih adalah Penelitian Tindakan Kelas (PTK). Penelitian ini dilaksanakan untuk melakukan perbaikan kualitas proses dan hasil pembelajaran dengan melakukan refleksi dan perbaikan pada tiap siklus. Penelitian ini dilaksanakan sebanyak 3 siklus dengan masing-masing siklus terdiri dari kegiatan perencanaan, pelaksanaan, pengamatan, dan refleksi. Metode yang digunakan untuk penelitian ini yaitu melalui model pembelajaran Problem Based Learning untuk dapat meningkatan hasil belajar siswa pada mata pelajaran IImu Pengetahuan Alam kelas IV SD Negeri Ngrajek 1.

Subjek dalam penelitian Penelitian Tindakan Kelas ini yaitu peserta didik kelas IV tahun ajaran 2020/2021 dengan jumlah sebanyak 24 peserta didik, yang terdiri dari 12 siswa laki-laki dan 12 siswa laki-laki. Tempat Penelitian Tindakan Kelas ini dilaksanakan di ruang kelas IV SD Negeri Ngrajek 1. Waktu penelitian berlangsung dari 2 November 2020 sampai dengan 28 November 2020.

Teknik analisis data yang digunakan dalam penelitian ini adalah analisis data secara kualitatif dan secara kuantitatif. Data kualitatif digunakan untuk menganalisis data yang berupa kata-kata atau informasi yang berbentuk kalimat pada lembar observasi. Data kuantitatif diperoleh dari soal evaluasi siswa menggunakan model Problem Based Learning (PBL). Data kuantitatif dalam penelitian tindakan kelas berupa angka-angka sederhana yang terdapat dalam hasil evaluasi. Data hasil evaluasi siswa dihitung skor masing-masing dan dari skor ditentukan nilai siswa menggunakan rumus sebagai berikut.

$$
\mathrm{P}=\frac{\sum \text { siswa yang tuntas belajar }}{\sum \text { siswa }} \times 100
$$

Setelah diketahui skor masing-masing, data dianalisis untuk mencari nilai ratarata kelas dengan menggunakan rumus sebagai berikut.

$$
\mathrm{Mx}=\frac{\Sigma X}{N}
$$

Keterangan :

$M x=$ Mean (rata-rata)

$\Sigma X \quad=$ Jumlah seluruh nilai siswa

$\mathrm{N} \quad=$ jumlah siswa 
Kriteria hasil belajar siswa rendah, sedang, atau tinggi dapat ditentukan dengan persentase sebagai berikut.

Tabel 2. Kriteria Hasil Belajar

\begin{tabular}{cc}
\hline Kriteria & Rentang persentase \\
\hline Sangat tinggi & $90-100 \%$ \\
Tinggi & $80-89 \%$ \\
Sedang & $70-79 \%$ \\
Rendah & $<69 \%$ \\
\hline
\end{tabular}

HASIL DAN PEMBAHASAN

Tabel 3. Hasil belajar pada Siklus I

\begin{tabular}{|c|c|c|c|c|}
\hline \multirow[b]{2}{*}{ Kriteria } & \multicolumn{2}{|c|}{ Pratindakan } & \multicolumn{2}{|c|}{ Siklus I } \\
\hline & Jumlah Siswa & $\begin{array}{c}\text { Persentase } \\
(\%)\end{array}$ & $\begin{array}{c}\text { Jumlah } \\
\text { Siswa }\end{array}$ & $\begin{array}{c}\text { Persentase } \\
(\%)\end{array}$ \\
\hline Tuntas & 9 & 37,5 & 16 & 66,7 \\
\hline Belum Tuntas & 15 & 62,5 & 8 & 33,3 \\
\hline Nilai rata-rata & \multicolumn{2}{|c|}{66,25} & \multicolumn{2}{|c|}{75} \\
\hline
\end{tabular}
berikut.

Adapun hasil belajar siswa pada siklus I dapat dilihat dalam diagram sebagai

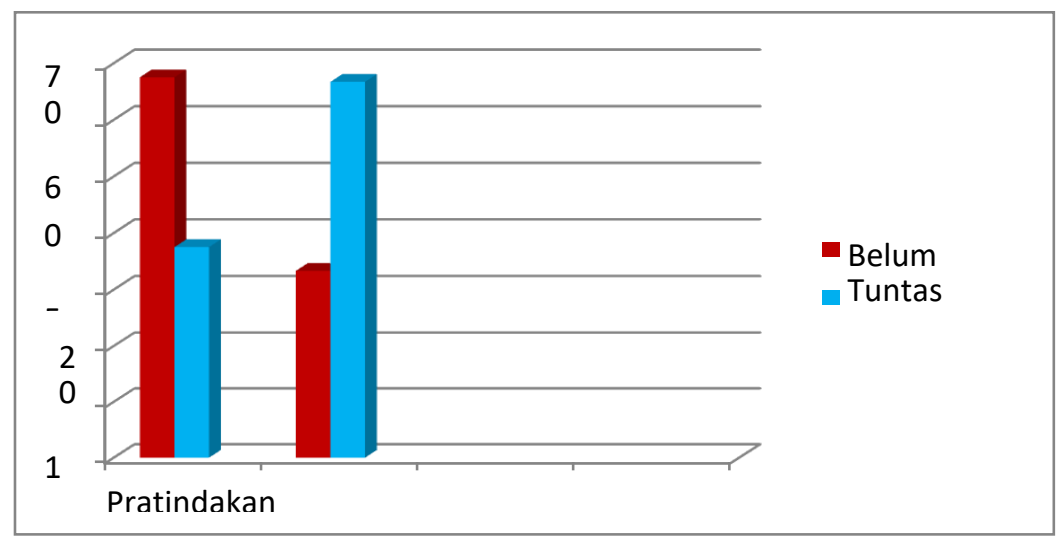

Gambar 1. Diagram Hasil Belajar pada Siklus I

Berdasarkan hasil belajar pada siklus I, dapat disimpulkan bahwa persentase siswa yang tuntas mengalami peningkatan, namun siklus I belum dikatakan berhasil karena dalam penelitian ini indikator keberhasilannya adalah $75 \%$ dari jumlah siswa yang memperoleh nilai $\geq 70$.

Tabel 4. Hasil Belajar pada Siklus II

\begin{tabular}{|c|c|c|c|c|c|c|}
\hline \multirow[b]{2}{*}{ Kriteria } & \multicolumn{2}{|c|}{ Pratindakan } & \multicolumn{2}{|c|}{ Siklus I } & \multicolumn{2}{|c|}{ Siklus II } \\
\hline & $\begin{array}{c}\text { Jumlah } \\
\text { Siswa }\end{array}$ & $\begin{array}{c}\text { Persentase } \\
(\%)\end{array}$ & $\begin{array}{c}\text { Jumlah } \\
\text { Siswa }\end{array}$ & $\begin{array}{c}\text { Persentase } \\
(\%)\end{array}$ & $\begin{array}{c}\text { Jumlah } \\
\text { Siswa }\end{array}$ & $\begin{array}{c}\text { Persentase } \\
(\%)\end{array}$ \\
\hline Tuntas & 9 & 37,5 & 16 & 66,7 & 20 & 83,3 \\
\hline $\begin{array}{l}\text { Belum } \\
\text { Tuntas }\end{array}$ & 15 & 62,5 & 8 & 33,3 & 4 & 16,7 \\
\hline $\begin{array}{l}\text { Nilai } \\
\text { rata-rata }\end{array}$ & \multicolumn{2}{|c|}{66,25} & \multicolumn{2}{|c|}{75} & \multicolumn{2}{|c|}{79} \\
\hline
\end{tabular}


Adapun hasil belajar hasil belajar siswa pada siklus II dapat dilihat dalam diagram berikut

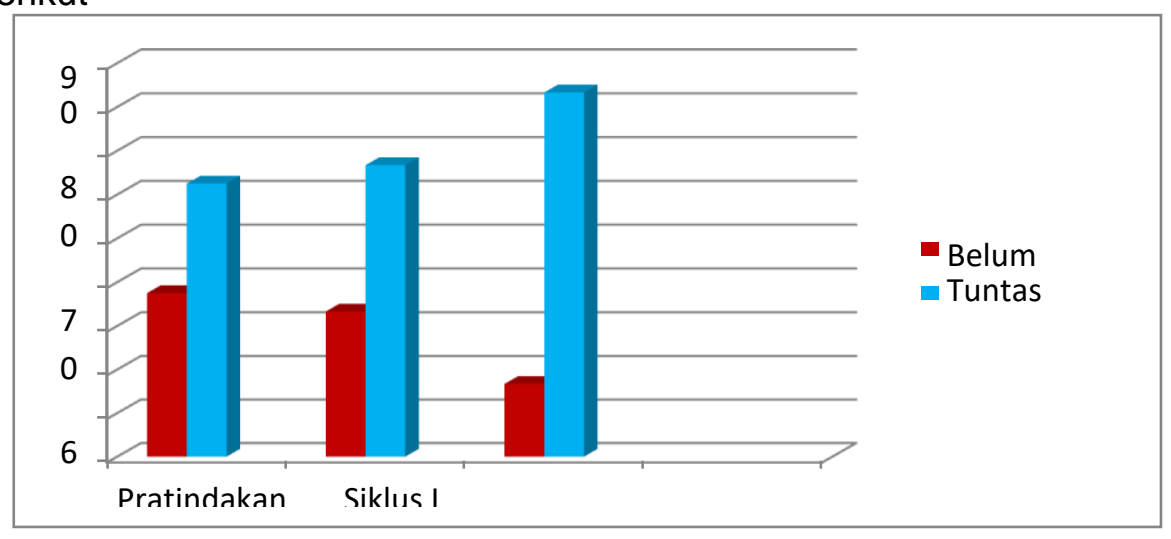

Gambar 2. Diagram Hasil Belajar pada Siklus II

Berdasarkan hasil belajar pada siklus II diatas dapat disimpulkan bahwa keberhasilan bahwa terdapat peningkatan nilai rata-rata siswa dari pratindakan hingga siklus II. Penelitian ini dikatakan berhasil karena indikator keberhasilannya lebih dari $75 \%$ dari jumlah siswa yang memperoleh nilai $>70$. Namun, peneliti akan melakukan siklus III untuk meningkatkan hasil belajar siswa dari kategori sedang menjadi kategori tinggi.

\begin{tabular}{lccccccccc}
\multicolumn{10}{c}{ Tabel 5. Hasil Belajar pada Siklus III } \\
\hline \multirow{2}{*}{ Kriteria } & \multicolumn{2}{c}{ Pratindakan } & \multicolumn{2}{c}{ Siklus I } & \multicolumn{2}{c}{ Siklus II } & \multicolumn{2}{c}{ Siklus III } \\
\cline { 2 - 11 } & $\begin{array}{c}\text { Jumlah } \\
\text { Siswa }\end{array}$ & $\begin{array}{c}\text { Perse } \\
\text { ntase } \\
(\%)\end{array}$ & $\begin{array}{c}\text { Jumlah } \\
\text { Siswa }\end{array}$ & $\begin{array}{l}\text { Perse } \\
\text { ntase } \\
(\%)\end{array}$ & $\begin{array}{c}\text { Jumlah } \\
\text { Siswa }\end{array}$ & $\begin{array}{c}\text { Perse } \\
\text { ntase } \\
(\%)\end{array}$ & $\begin{array}{c}\text { Jumlah } \\
\text { Siswa }\end{array}$ & $\begin{array}{c}\text { Perse } \\
\text { ntase } \\
(\%)\end{array}$ \\
\hline $\begin{array}{l}\text { Tuntas } \\
\begin{array}{l}\text { Belum } \\
\text { Tuntas }\end{array}\end{array}$ & 9 & 37,5 & 16 & 66,7 & 20 & 83,3 & 24 & 100 \\
$\begin{array}{l}\text { Nilai } \\
\text { rata-rata }\end{array}$ & 15 & $62,5 \%$ & 8 & 33,3 & 4 & 16,7 & 0 & 0 \\
\hline
\end{tabular}
berikut

Hasil belajar hasil belajar siswa pada siklus III dapat dilihat dalam diagram

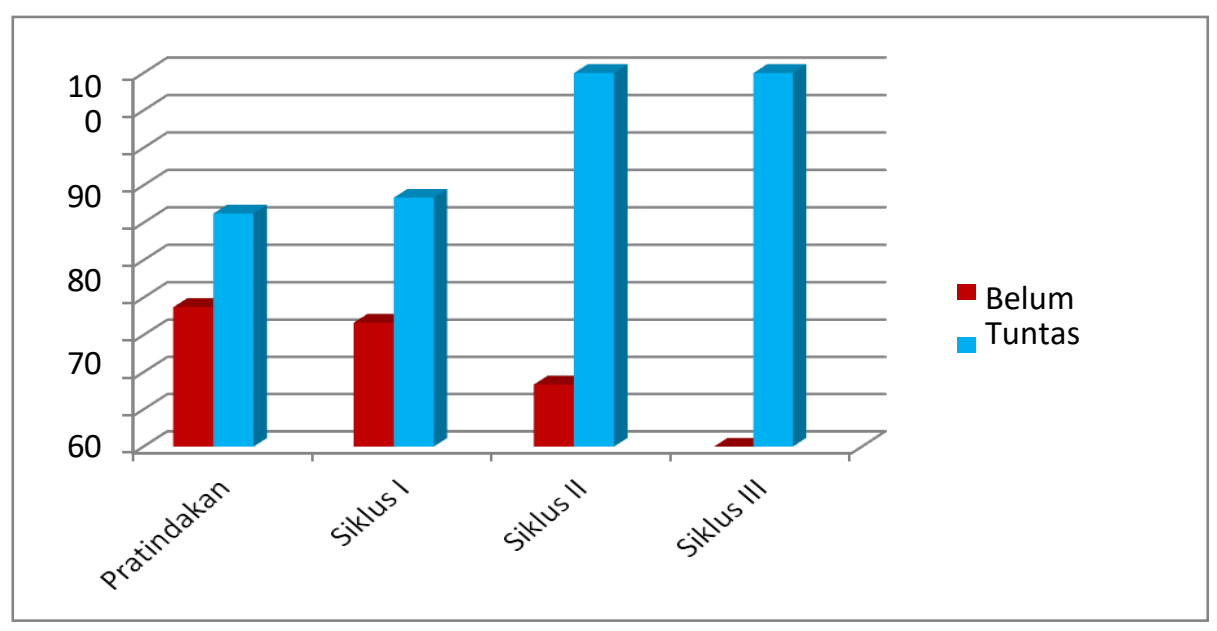

Gambar 3. Diagram Hasil Belajar pada Siklus III 
Berdasarkan hasil belajar pada siklus III diatas dapat disimpulkan bahwa terdapat peningkatan nilai rata-rata siswa dari pratindakan hingga siklus III. Penelitian ini dikatakan berhasil karena indikator keberhasilannya lebih dari $75 \%$ dari jumlah siswa yang memperoleh nilai > 70 dan nilai rata-rata siswa secara klasikal tuntas dengan kategori tinggi yaitu 81.

Berdasarkan hasil penelitian, penerapan pembelajaran dengan model Problem Based Learning (PBL) dapat meningkatkan keaktifan siswa dan hasil belajar siswa. Hal ini dapat dilihat dari hasil observasi dan hasil belajar siswa dalam proses pembelajaran tematik yang semula sebelum diberikan tindakan mencapai $37,5 \%$ pada siklus I meningkat menjadi 66,7\% Pada siklus II siswa sudah mempunyai pengalaman mengikuti pembelajaran dengan model Problem Based Learning (PBL) pada siklus I. Sehingga pada siklus II siswa sudah tidak mengalami kesulitan mengikuti pembelajaran dengan model Problem Based Learning (PBL). Siswa juga sudah memiliki rasa percaya diri ketika melakukan presentasi hasil laporanya di depan siswa lain melaui google meet. Dan keaktifan siswa dalam mengikuti pembelajaran juga meningkat. Seperti aktif dalam memberikan jawaban ketika ada soal yang diberikan oleh guru. Namun siswa masih malu untuk bertanya ketika diberikan kesempatan bertanya oleh guru. Lebih lanjut, persentase siswa yang dikategorikan tuntas belajar mengalami peningkatan sebesar $45,8 \%$ yang semula $37,5 \%$ menjadi $83,3 \%$. Selain itu pada siklus II nilai rata-rata siswa juga mengalami peningkatan sebesar 12,5 , yang semula rata-rata siswa 66,5 pada siklus II nilai rata-rata sebesar 79 . Namun rata-rata nilai siswa tersebut masih dalam kategori sedang dalam interval 70-79, maka peneliti melakukan siklus III untuk meningkatkan hasil belajar siswa dalam kategori tinggi.

Pembelajaran pada siklus III menunjukkan aktivitas keaktifan siswa mendengarkan penjelasan guru, memberikan berpendapat atau jawaban dalam proses pembelajaran mengalami peningkatan. Refleksi yang ada pada siklus II sudah dilaksanakan pada siklus III. Seperti pada siklus II siswa masih malu bertanya kepada guru pada pembelajaran siklus III siswa sudah berani untuk bertanya. Siswa secara klasikal sudah aktif dalam mengikuti proses pembelajaran. Lebih lanjut, persentase siswa yang dikategorikan tuntas belajar mengalami peningkatan sebesar $62,5 \%$ yang semula $37,5 \%$ menjadi $100 \%$. Pada siklus III nilai rata-rata siswa juga mengalami peningkatan sebesar 14,5 , yang semula rata-rata siswa 66,5 pada siklus III nilai ratarata sebesar 81 .

\section{SIMPULAN}

Berdasarkan hasil penelitian dan pembahasan, dapat disimpulkan bahwa penerapan model Problem Based Learning (PBL) dapat meningkatkan hasil belajar siswa kelas IV SD Negeri Ngrajek 1, Ngrajek, Mungkid, Magelang. Peningkatan hasil belajar siswa ditunjukkan dengan adanya peningkatan nilai rata-rata siswa dan proses pembelajaran.

Peningkatan proses pembelajaran yang semula menggunakan model pembelajaran yang masih konvensional melalui penelitian ini model pembelajaran yang diterapkan telah mengaktifkan siswa dalam mengikuti pembelajaran. Model yang diterapkan yaitu Problem Based Learning (PBL), melalui langkah-langkah pada model Problem Based Learning (PBL), pembelajaran lebih bermakna siswa dilatih untuk berpikir kritis. Sehingga terdapat peningkatan hasil belajar ditunjukkan dengan adanya peningkatan nilai rata-rata dan jumlah siswa yang mencapai indikator yang telah ditentukan yaitu 70 .

Hasil belajar pratindakan memperoleh nilai ratarata sebesar 66,25 , pada siklus I nilai rata-rata yang diperoleh sebesar 75 , pada siklus II nilai rata-rata yang diperoleh sebesar 79 dan pada siklus III nilai rata-rata yang diperoleh sebesar 81. Persentase siswa yang mencapai indikator yang ditentukan atau siswa yang mencapai nilai 70 pada pratindakan sebesar $37,5 \%$, pada siklus I sebesar $66,7 \%$, pada siklus II sebesar 
$83,3 \%$ dan pada siklus III 100\%. Berdasarkan hasil tersebut menunjukkan bahwa penerapan model Problem Based Learning (PBL) dalam pembelajaran telah memenuhi kriteria keberhasilan proses dan produk dalam penelitian ini. Sehingga dapat disimpulkan bahwa penelitian ini berhasil meningkatkan hasil belajar siswa pada mata pelajaran Ilmu pengetahuan Alam.

\section{DAFTAR PUSTAKA}

Abidin, Y. (2016). Desain Sistem Pembelajaran Dalam Konteks Kurikulum 2013. Bandung: Refika Aditama.

Amir, M.T. (2019). Inovasi Pendidikan Melalui Problem Based Learning: Bagaimana Pendidik Memberdayakan Pemelajar Di Era Pengetahuan. Jakarta: Kencana.

Mulyasa. (2014). Guru dalam Implementasi Kurikulum 2013. Bandung: Remaja Rosdakarya. Nur,M. (2015). Model Pembelajaran Berdasarkan Masalah. Surabaya : Pusat Sains dan IPA Sekolah Unesa.

Rusman. (2018). Model-Model Pembelajaran (Mengembangkan Profesionalisme Guru).Jakarta: Raja Grafindo Persda.

Rusman. (2018). Pembelajaran Tematik Terpadu Teori, Praktik dan Penilaian. Jakarta: Rajawali Pers.

Sagala, S. (2019). Supervisi Pembelajaran Dalam Profesi Pendidikan: Membantu Mengatasi Kesulitan Guru Memberikan Tujuan Belajar Yang Bermutu. Bandung: Alfabeta,

Shoimin, A. (2017). Model Pembelajaran Inovatif Dalam Berkurikulum 2013. Yogyakarta : AR-RUZZ Media.

Sudjana, N. (2018). Dasar-Dasar Proses Belajar Mengajar. Bandung: Sinar Baru Algensindo.

Suprijono,A. (2015). Model-Model Pembelajaran. Jakarta: Gramedia Pustaka Jaya. Syarif, M. (2018). Strategi Pembelajaran. Jakarta : Rajagrafindo Persada.

Trianto. (2015). Mendesian Model Pembelajaran Inovatif-Progresif. Jakarta: Kencana

Wulandari, B. ( 2016). Pengaruh Problem-Based Learning terhadap hasil belajar ditinjau dari motivasi belajar PLC di SMK". Jurnal Pendidikan Vokasi. $3(2): 180$.

Zusnani, I. (2016). Pendidikan Kepribadian Siswa SD-SMP. Yogyakarta: Tugu Publisher. 